\title{
Fear Factor: The AIS Course And Non- Positive Attitudes Towards Computers
}

Ronald J. Daigle, (Email: rjdaigle@1su.edu), Louisiana State University

Philip W. Morris, (Email: Morris@shsu.edu), Sam Houston State University

\begin{abstract}
Students provide their computer attitudes before and after taking an introductory AIS course, and are classified as having positive or non-positive attitudes before the course. Those with some degree of a non-positive attitude are influenced most - and positively so - by the course. No gender differences are noted. While these findings are promising, some aspects of non-positive attitudes do not improve and gaps still exist between partitioned groups. Prior computer experience helps explain prior attitudes. Impact of findings is discussed.
\end{abstract}

\section{INTRODUCTION}

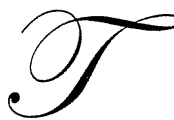

he pervasiveness of computer technology in business demands that accounting professionals have proficient computer skills to be successful. This expectation is evidenced by coverage of various technology-related concepts on respective Uniform CIA, CPA, CMA and CFM examinations (AICPA, 2005; IIA, 2005; IMA, 2005). Accounting information system (AIS) courses directly help students acquire needed computer skills for their careers.

The importance of AIS courses cannot be minimized when considering that both an accounting professional's work performance and satisfaction can be affected by his or her attitudes toward computer technology (Ferguson, 1997; Mills, 1997). Even before entering the profession, students can be apprehensive towards and uneasy with AIS course material (Jones, 2001; Dunn and Grabski, 1999; Briscoe et al., 1996; Ravel, 1991). This potential "fear factor" with AIS course material necessitates the need for studying the relationship between AIS courses and student attitudes towards computer technology. Such studies can help improve the chances of accounting students performing well and being satisfied with their future careers.

Prior studies (Morris and Daigle, 2004; Basile and D'Aquila, 2002) indicate that students generally have positive computer attitudes, both before and after computer exposure in an accounting course, including an AIS course. These studies also report that computer exposure does not generally change attitudes, with the exposure appearing to reinforce already existing positive attitudes. Such results may indicate that AIS educators should not be overly concerned with students having negative attitudes towards AIS course material. However, prior studies have focused on attitudes of accounting students in the aggregate or as a whole. Our study differs by categorizing individual students into segments or groups based on their attitudes before taking an AIS course. By doing so, we report a number of interesting findings.

Our study analyses survey responses from students both before and after taking an introductory AIS course. We use two methods to classify respondents between those who have positive computer attitudes and those who exhibit some degree of a non-positive attitude (either neutral or negative), before the course. Depending on the partition, results show that $20-40 \%$ of those surveyed report some degree of a non-positive attitude towards computers before taking an AIS course, and the non-positive attitude most often exhibited is that of "not liking computers." Results also show that students with some degree of a non-positive attitude are the ones influenced by the AIS course, with significant improvements in their attitudes at end of the semester. While the gap between those with positive attitudes and those with some degree of a non-positive attitude decreases, results show the gap is still quite substantial at end of semester. 
Results also show no differences by gender, a result that differs from many prior studies of students, in general, but is consistent with the few studies that focus on accounting students (Morris and Daigle, 2004; Basile and D'Aquila, 2002; Daigle and Morris, 1999; Orpen and Ferguson, 1991). A further result of our study shows that, consistent with much prior research, prior computer experience helps explain prior computer attitudes - students with positive (non-positive) attitudes have significantly more (less) computer experience. Further exploratory analyses of students surveyed who report negative attitudes at the beginning of semester reinforce many of these results. Our findings should be of interest and use to both accounting and AIS educators for assessing whether their curriculums are providing sufficient computer exposure before students graduate and enter the profession.

The next section of this paper discusses prior literature and research questions of interest. Further sections provide methodology and analysis of survey results. The last section summarizes results and discusses implications of the study.

\section{PRIOR LITERATURE AND RESEARCH QUESTIONS}

Many studies over the last twenty-five years have tried to identify factors that influence computer attitudes, with one such factor being computer experience. Although some studies have reported otherwise (for example, Torkzadeh and Koufteros, 1993), most studies consistently report that exposure to computer technology generally improves a person's attitude towards computers, especially in courses that focus on acquiring substantial computer skills (for example, Harris, 1992; Omar, 1991). Less is known, however, about the influence of AIS courses on accounting student attitudes towards computers.

While introductory AIS courses expose students to computer technology, they are generally not as technology-intensive as typical information systems courses, focusing instead on teaching accounting and system concepts with technology a component for having effective and efficient AIS activities (Bain et al., 2002). The hybrid nature of AIS courses (part accounting, part computer course) can easily lead to a conflict between: 1) the assumption, based on prior studies of computer exposure, that attitudes towards AIS material that incorporates technology should improve after the exposure, and 2) concerns that typically subjective AIS course material is not embraced as much by accounting students as objective material found in other traditional accounting courses (Dunn and Grabski, 1998; Ravel, 1991). Concerns are reinforced by findings that AIS courses and their instructors typically receive lower evaluation scores than other accounting courses and their instructors (Jones, 2001; Briscoe et al., 1996). The subjective nature of much AIS course material is cited as a reason for this result.

A few studies have focused on accounting student attitudes towards computers. Orpen and Ferguson (1991) survey students near the time of completing their studies and find a direct relationship between computer experience and attitudes. They also find that students generally report positive attitudes and high levels of experience. Basile and D'Aquila (2002) find that students in a financial accounting course that included computer-based assignments generally report positive attitudes both before and after the course, and attitudes unchanged by computer exposure. Morris and Daigle (2004) also find that students, this time in an introductory AIS course, generally report positive attitudes towards computers, both before and after the course. Consistent with Basile and D'Aquila (2002), attitudes reported do not differ significantly from beginning to end of semester. Both Basile and D'Aquila (2002) and Morris and Daigle (2004) also report substantial levels of prior computer exposure.

All three studies cited that focus on accounting students report positive computer attitudes and high levels of computer experience. However, Basile and D'Aquila (2002) and Morris and Daigle (2004) also report a conflicting result - further exposure, including in an AIS course, does not change attitudes. While all three studies appear to indicate that the concerns expressed by Dunn and Grabski (1998) and Ravel (1991) may not be overly warranted, course evaluation results reported by Jones (2001) and Briscoe et al. (1996) provide conflicting results.

Besides these conflicting results, all three studies report on accounting students as an aggregated whole and not as individuals or segments. This is important because Jones (2001) reports: 1) a great deal of variation exists amongst students with respect to their comfort with computers and 2) many students can have less favorable attitudes after computer exposure. These findings, as well as the relationship between computer attitudes and both individual 
work performance and satisfaction (Ferguson, 1997; Mills, 1997), require that students be studied at a less aggregated level than in grand total, specifically within AIS courses. We choose to study for differences between students with positive attitudes versus students with non-positive attitudes. We therefore ask the following research question:

R1: Does an introductory AIS course have a different influence on students with non-positive computer attitudes before taking the course than students with positive attitudes?

Over the last quarter century the relationship between gender and computer attitudes has been repeatedly studied. Some studies report that males have more favorable attitudes (i.e., Sax, 2000; Young, 2000) while others report no difference (i.e., Orr et al., 2001; Seyal et al., 2002). Amongst accounting students, the results are more consistent with no difference noted in the three studies previously cited, as well as Daigle and Morris (1999), which specifically focuses on the relationship between gender and computer attitudes across an accounting curriculum. Even so, all of these studies deal with accounting students in aggregate. It is therefore of interest to determine the relationship between non-positive computer attitudes, gender, and an introductory AIS class at a less aggregated level. This leads to our second research question:

R2: Does the introductory AIS course have a different influence on students with non-positive computer attitudes before taking the course than students with positive attitudes, based on gender?

Prior research measuring computer attitudes of students, in general, and accounting students, in particular, report a direct relationship between prior computer experience and computer attitudes. With prior accounting studies focusing on students in the aggregate, we ask the following research question:

R3: Do students with non-positive computer attitudes before taking an introductory AIS course and students with positive attitudes differ also in prior computer experience?

Each university is located in the southern part of the United States, with student bodies of approximately 13,000 (University A), 16,000 (University B), 30,000 (University C), and 30,000 (University D), respectively. Each university's accounting department offers an undergraduate accounting degree and master's degree that allows students to meet the 150-hour rule for taking the CPA exam. All accounting majors at each university are required to take the introductory AIS course, which can also be taken as an elective by other majors. Consistent at each university, an introductory college computer course must be taken as a prerequisite to the AIS course.

Though material covered differed slightly between the four universities, each course covered many similar topics, including transaction cycles, information systems structure and design, e-commerce, internal control, and computer fraud and security. Each university incorporated hands-on experience with certain forms of technology:

- Excel and Oracle at University A

- Internet and Excel at University B

- Microsoft Great Plains Dynamics, Access, and Excel at University C

- Microsoft Great Plains Dynamics and Excel at University D

Students completed the survey during the first week of the semester, and provided responses again to the attitude statements during the final week of the semester. Students were asked to provide the last six digits of their Social Security number at both times for matching beginning and end of semester responses. Students were assured that the confidentiality of their responses would be protected. Only matched surveys from students who completed both at beginning and end of semester are used, resulting in a useable sample of 252 matched pairs ${ }^{1}$. 
Table 1 - Mean Responses to Experience Questions at Beginning of Semester by Partition

\begin{tabular}{|c|c|c|c|c|c|c|c|c|}
\hline Item & Experience Question & $\begin{array}{c}\text { Mean } \\
<= \\
30\end{array}$ & $\begin{array}{l}\text { Mean } \\
> \\
\mathbf{3 0}\end{array}$ & $\begin{array}{c}\text { Two- } \\
\text { tailed } \\
\text { p-value }\end{array}$ & $\begin{array}{l}\text { Mean } \\
<= \\
35\end{array}$ & $\begin{array}{l}\text { Mean } \\
> \\
35\end{array}$ & $\begin{array}{c}\text { Two- } \\
\text { tailed } \\
\text { p-value }\end{array}$ & Note $^{1}$ \\
\hline E6 & $\begin{array}{l}\text { Please enter the length of time in years that you } \\
\text { have used computers. }\end{array}$ & 8.37 & 10.59 & 0.0012 & 9.01 & 10.81 & 0.0027 & A \\
\hline E7 & $\begin{array}{l}\text { If you have access to a personal computer at } \\
\text { home, how often do you use it? }\end{array}$ & 4.15 & 4.74 & 0.0184 & 4.34 & 4.78 & 0.0046 & $\mathrm{~B}$ \\
\hline E8 & How often do you use the college computer labs? & 3.65 & 3.21 & 0.0167 & 3.65 & 3.09 & 0.0003 & $\mathrm{~B}$ \\
\hline E9 & $\begin{array}{l}\text { If you have access to a computer at work, how } \\
\text { often do you use it? }\end{array}$ & 2.71 & 3.72 & 0.0072 & 3.14 & 3.74 & 0.0434 & $\mathrm{~B}$ \\
\hline E10 & $\begin{array}{l}\text { In primary and secondary school, how many } \\
\text { semesters of computer-related courses have you } \\
\text { taken? }\end{array}$ & 2.48 & 2.81 & 0.3539 & 2.62 & 2.81 & 0.5443 & A \\
\hline E11 & $\begin{array}{l}\text { In college, how many semesters of computer- } \\
\text { related courses have you taken? }\end{array}$ & 2.64 & 3.08 & 0.1270 & 2.82 & 3.08 & 0.3732 & A \\
\hline E12 & $\begin{array}{l}\text { Through work, how many days ( } 1 \text { day }=8 \text { hours) } \\
\text { of formal computer training have you had? }\end{array}$ & 4.46 & 13.55 & 0.0662 & 3.10 & 16.67 & 0.0550 & A \\
\hline E13 & $\begin{array}{l}\text { Do you have experience using the computer for } \\
\text { playing games? }\end{array}$ & 1.12 & 1.07 & 0.2979 & 1.12 & 1.05 & 0.0851 & C \\
\hline E14 & $\begin{array}{l}\text { How often do you use the computer for playing } \\
\text { games? }\end{array}$ & 2.88 & 3.18 & 0.0706 & 2.95 & 3.22 & 0.0440 & B \\
\hline E15 & $\begin{array}{l}\text { Do you have experience using the computer for } \\
\text { data entry? }\end{array}$ & 1.12 & 1.05 & 0.1400 & 1.07 & 1.05 & 0.4811 & $\mathrm{C}$ \\
\hline E16 & $\begin{array}{l}\text { How often do you use the computer for data } \\
\text { entry? }\end{array}$ & 3.29 & 3.80 & 0.0156 & 3.52 & 3.80 & 0.0858 & B \\
\hline E17 & $\begin{array}{l}\text { Do you have experience using the computer for } \\
\text { word processing? }\end{array}$ & 1.04 & 1.00 & 0.1593 & 1.02 & 1.00 & 0.1584 & C \\
\hline E18 & $\begin{array}{l}\text { How often do you use the computer for word } \\
\text { processing? }\end{array}$ & 3.79 & 4.11 & 0.0139 & 3.86 & 4.15 & 0.0035 & B \\
\hline E19 & $\begin{array}{l}\text { Do you have experience using the computer for } \\
\text { spreadsheets? }\end{array}$ & 1.17 & 1.03 & 0.0109 & 1.13 & 1.02 & 0.0035 & $\mathrm{C}$ \\
\hline E20 & $\begin{array}{l}\text { How often do you use the computer for } \\
\text { spreadsheets? }\end{array}$ & 3.69 & 3.52 & 0.8736 & 3.53 & 3.57 & 0.9376 & B \\
\hline E21 & $\begin{array}{l}\text { Do you have experience using the computer for } \\
\text { programming? }\end{array}$ & 1.87 & 1.58 & $<0.0001$ & 1.82 & 1.52 & $<0.0001$ & $\mathrm{C}$ \\
\hline E22 & $\begin{array}{l}\text { How often do you use the computer for } \\
\text { programming? }\end{array}$ & 1.12 & 1.49 & $<0.0001$ & 1.16 & 1.56 & $<0.0001$ & B \\
\hline E23 & $\begin{array}{l}\text { Do you have experience using the computer for } \\
\text { statistical analysis? }\end{array}$ & 1.62 & 1.34 & 0.0005 & 1.52 & 1.32 & 0.0031 & $\mathrm{C}$ \\
\hline E24 & $\begin{array}{l}\text { How often do you use the computer for statistical } \\
\text { analysis? }\end{array}$ & 1.48 & 1.91 & 0.0021 & 1.59 & 1.96 & 0.0021 & B \\
\hline E25 & $\begin{array}{l}\text { Do you have experience using the computer for } \\
\text { database management? }\end{array}$ & 1.73 & 1.49 & 0.0023 & 1.66 & 1.47 & 0.0025 & $\mathrm{C}$ \\
\hline E26 & $\begin{array}{l}\text { How often do you use the computer for database } \\
\text { management? }\end{array}$ & 1.37 & 1.88 & 0.0006 & 1.46 & 1.96 & 0.0004 & B \\
\hline $\mathrm{E} 27$ & $\begin{array}{l}\text { Do you have experience using the computer for } \\
\text { email? }\end{array}$ & 1.08 & 1.00 & 0.3220 & 1.04 & 1.00 & 0.3199 & $\mathrm{C}$ \\
\hline E28 & How often do you use the computer for e-mail? & 4.54 & 4.79 & 0.0554 & 4.58 & 4.83 & 0.0055 & B \\
\hline E29 & $\begin{array}{l}\text { Do you have experience using the computer for } \\
\text { internet searching? }\end{array}$ & 1.06 & 1.00 & 0.3220 & 1.03 & 1.00 & 0.3199 & $\mathrm{C}$ \\
\hline E30 & $\begin{array}{l}\text { How often do you use the computer for internet } \\
\text { searching? }\end{array}$ & 4.46 & 4.60 & 0.2320 & 4.45 & 4.64 & 0.0216 & $\mathrm{~B}$ \\
\hline E31 & $\begin{array}{l}\text { Do you have experience using the computer for } \\
\text { preparing slide/photo presentations? }\end{array}$ & 1.33 & 1.22 & 0.1288 & 1.32 & 1.19 & $\mathbf{0 . 0 3 7 3}$ & $\mathrm{C}$ \\
\hline E32 & $\begin{array}{l}\text { How often do you use computer for preparing } \\
\text { slide/photo presentations? }\end{array}$ & 1.92 & 2.20 & 0.0449 & 1.93 & 2.27 & 0.0035 & B \\
\hline
\end{tabular}

A: The actual amount of time (in years, days, or semesters depending on the question).

B: A scale of 1 to 5 with $5=$ Almost every day, $4=$ At least once a week, $3=$ Every one or two months, $2=$ Once or twice a year, and $1=$ Never. C: A binary response of 1 or 2 with $1=$ Yes and $2=$ No.

${ }^{2}$ All bolded p-values are significant at $<0.10$. Except for E8, all bolded p-values indicate that students whose scores on all three computer attitude scales are above 30 (35) have more experience with respect to the given question than students whose scores are equal to or less than 30 (35) in at least one computer attitude category. The p-value for E8 indicates that students whose scores are equal to or less than 30 (35) in at least one computer attitude category have more significantly more experience than students whose scores on all three computer attitude scales are above 30 (35). 
Factor analysis by the developers of the CAS show that the thirty attitude statements individually load onto one of three general factors (subscales): 1) Computer Anxiety (fear of computers), 2) Computer Confidence (ability to use or learn about computers), and 3) Computer Liking (enjoy working with computers) ${ }^{2}$. Subscale statements are mixed throughout the instrument with some positively worded and others negatively worded for ensuring attention to responses. A five-point Likert Scale is used and responses are recoded and summed to provide a given subscale score. A subscale score can be between 10 and 50 , with 30 a perfectly neutral attitude. To interpret, the greater a particular score, the less computer anxiety and the more computer confidence and computer liking a respondent has.

\section{Identifying Students With Non-Positive Attitudes}

We use two approaches to identify students with at least some degree of having a non-positive attitude towards computers. First, we partition students if they have a score of 30 or less on any subscale at the beginning of the semester. This results in 52 matched pairs (21\% of the sample) of students with some degree of a non-positive attitude and 200 matched pairs (79\%) having a positive attitude. A detail of students by university and gender is shown in Table 3.

Table 2 - Statements for Each Subscale of the Computer Attitude Scale

\begin{tabular}{|c|c|}
\hline Item & Item \\
\hline & Computer Anxiety \\
\hline 1 & Computers do not scare me at all. \\
\hline 4 & Working with a computer would make me very nervous. \\
\hline 7 & I do not feel threatened when others talk about computers. \\
\hline 10 & I feel aggressive and hostile towards computers. \\
\hline 13 & It wouldn't bother me at all to take computer courses. \\
\hline 16 & Computers make me feel uncomfortable. \\
\hline 19 & I would feel at ease in a computer class. \\
\hline 22 & I get a sinking feeling when I think of trying to use a computer. \\
\hline 25 & I would feel comfortable working with a computer. \\
\hline \multirow[t]{2}{*}{28} & Computers make me feel uneasy and confused. \\
\hline & Computer Confidence \\
\hline 2 & I'm no good with computers. \\
\hline 5 & Generally, I would feel OK about trying a new problem on the computer. \\
\hline 8 & I don't think I would do advanced computer work. \\
\hline 11 & I am sure I could do work with computers. \\
\hline 14 & I'm not the type to do well with computers. \\
\hline 17 & I am sure I could learn a computer language. \\
\hline 20 & I think using a computer would be very hard for me. \\
\hline 23 & I could get good grades in computer courses. \\
\hline 26 & I do not think I could handle a computer course. \\
\hline \multirow[t]{2}{*}{29} & I have a lot of self-confidence when it comes to working with computers. \\
\hline & Computer Liking \\
\hline 3 & I would like working with computers. \\
\hline 6 & The challenge of solving problems with computers does not appeal to me. \\
\hline 9 & I think working with computers would be enjoyable and stimulating. \\
\hline 12 & Figuring out computer problems does not appeal to me. \\
\hline 15 & $\begin{array}{l}\text { When there is a problem using a computer application that I can't immediately solve, I would stick with it } \\
\text { until I have the answer. }\end{array}$ \\
\hline 18 & I don't understand how some people can spend so much time working with computers and seem to enjoy it. \\
\hline 21 & Once I start to work with the computer, I would find it hard to stop. \\
\hline 24 & I will do as little work with computers as possible. \\
\hline 27 & If a problem is left unsolved in a computer class, I would continue to think about it afterward. \\
\hline 30 & I do not enjoy talking with others about computers. \\
\hline
\end{tabular}


Second, we use a score of 35 as the cutoff in any subscale. This cutoff is chosen because it is halfway between a perfectly neutral attitude (30) and one definitely positive (40). This results in 95 matched pairs (38\%) of students with some degree of a non-positive attitude and 157 matched pairs $(62 \%)$ of students having a positive attitude. Table 4 provides student detail by both university and gender.

Both sets of partitions provide an interesting insight not reported in Morris and Daigle (2004). A substantial number of students surveyed $(21 \%$ and $38 \%$ ) have some degree of a non-positive attitude. These percentages verify the need for studying the influence of an introductory AIS course on attitudes of students with non-positive attitudes towards computers.

Table 3 - Breakdown of Students by University and Gender Using Score Partition of 30

\begin{tabular}{|c|c|c|c|c|c|c|}
\hline & $\begin{array}{c}\text { Matched Pairs with } \\
\text { Beginning of } \\
\text { Semester Score }<=30 \\
\text { on at Least One Scale }\end{array}$ & $\begin{array}{c}\text { \% of } \\
\text { Column } \\
\text { Total }\end{array}$ & $\begin{array}{l}\text { Matched Pairs with } \\
\text { Beginning of } \\
\text { Semester Score }>\mathbf{3 0} \\
\text { on All Scales }\end{array}$ & $\begin{array}{l}\text { \% of } \\
\text { Column } \\
\text { Total }\end{array}$ & $\begin{array}{l}\text { Total } \\
\text { Matched } \\
\text { Pairs }\end{array}$ & $\begin{array}{c}\text { \% of } \\
\text { Column } \\
\text { Total }\end{array}$ \\
\hline \multicolumn{7}{|l|}{ University A: } \\
\hline Female & 7 & $13.46 \%$ & 35 & $17.50 \%$ & 42 & $16.67 \%$ \\
\hline Male & 5 & $9.62 \%$ & 23 & $11.50 \%$ & 28 & $11.11 \%$ \\
\hline Total & 12 & $23.08 \%$ & 58 & $29.00 \%$ & 70 & $27.78 \%$ \\
\hline \multicolumn{7}{|l|}{ University B: } \\
\hline Female & 6 & $11.54 \%$ & 29 & $14.50 \%$ & 35 & $13.89 \%$ \\
\hline Male & 1 & $1.92 \%$ & 13 & $6.50 \%$ & 14 & $5.56 \%$ \\
\hline Total & 7 & $13.46 \%$ & 42 & $21.00 \%$ & 49 & $19.44 \%$ \\
\hline \multicolumn{7}{|l|}{ University C: } \\
\hline Female & 12 & $23.08 \%$ & 29 & $14.50 \%$ & 41 & $16.27 \%$ \\
\hline Male & 8 & $15.38 \%$ & 23 & $11.50 \%$ & 31 & $12.30 \%$ \\
\hline Total & 20 & $38.46 \%$ & 52 & $26.00 \%$ & 72 & $28.57 \%$ \\
\hline \multicolumn{7}{|l|}{ University D: } \\
\hline Female & 11 & $21.15 \%$ & 29 & $14.50 \%$ & 40 & $15.87 \%$ \\
\hline Male & 2 & $3.85 \%$ & 19 & $9.50 \%$ & 21 & $8.33 \%$ \\
\hline Total & 13 & $25.00 \%$ & 48 & $24.00 \%$ & 61 & $24.21 \%$ \\
\hline \multicolumn{7}{|l|}{ Grand Total: } \\
\hline Female & 36 & $69.23 \%$ & 122 & $61.00 \%$ & 158 & $62.70 \%$ \\
\hline Male & 16 & $30.77 \%$ & 78 & $39.00 \%$ & 94 & $37.30 \%$ \\
\hline Total & 52 & $100.00 \%$ & 200 & $100.00 \%$ & 252 & $100.00 \%$ \\
\hline
\end{tabular}

Further insights are gained from the data in Tables 3 and 4. No university dominates the percentage composition of total students in any column in either table, with general consistency across universities amongst students with positive attitudes $\left(2^{\text {nd }}\right.$ column $)$ and in total $\left(3^{\text {rd }}\right.$ column). By gender, partitions by university and in total are also generally consistent in both the second and third columns of both tables for each partitioned group. While University B consistently has fewer students and University C more students with some degree of a non-positive attitude than Universities A and D in both tables, sample sizes for Universities B and C do not skew subject composition by either gender or in total in the first column. Consistency across universities and by gender improves the external validity of conclusions reached from studying the data. 
Table 4-Breakdown of Students by University and Gender Using Score Partition of 35

\begin{tabular}{|c|c|c|c|c|c|c|}
\hline & $\begin{array}{c}\text { Matched Pairs with } \\
\text { Beginning of Semester } \\
\text { Score }<=35 \text { on at Least } \\
\text { One Scale }\end{array}$ & $\begin{array}{c}\% \text { of } \\
\text { Column } \\
\text { Total } \\
\end{array}$ & $\begin{array}{c}\text { Matched Pairs with } \\
\text { Beginning of Semester } \\
\text { Score }>35 \text { on All } \\
\text { Scales } \\
\end{array}$ & $\begin{array}{c}\% \text { of } \\
\text { Column } \\
\text { Total } \\
\end{array}$ & $\begin{array}{l}\text { Total } \\
\text { Matched } \\
\text { Pairs } \\
\end{array}$ & $\begin{array}{c}\% \text { of } \\
\text { Column } \\
\text { Total } \\
\end{array}$ \\
\hline \multicolumn{7}{|l|}{ University A: } \\
\hline Female & 18 & $18.95 \%$ & 24 & $15.29 \%$ & 42 & $16.67 \%$ \\
\hline Male & 8 & $8.42 \%$ & 20 & $12.74 \%$ & 28 & $11.11 \%$ \\
\hline Total & 26 & $27.37 \%$ & 44 & $28.03 \%$ & 70 & $27.78 \%$ \\
\hline \multicolumn{7}{|l|}{ University B: } \\
\hline Female & 10 & $10.53 \%$ & 25 & $15.92 \%$ & 35 & $13.89 \%$ \\
\hline Male & 2 & $2.11 \%$ & 12 & $7.64 \%$ & 14 & $5.56 \%$ \\
\hline Total & 12 & $12.63 \%$ & 37 & $23.57 \%$ & 49 & $19.44 \%$ \\
\hline \multicolumn{7}{|l|}{ University C: } \\
\hline Female & 20 & $21.05 \%$ & 21 & $13.38 \%$ & 41 & $16.27 \%$ \\
\hline Male & 13 & $13.68 \%$ & 18 & $11.46 \%$ & 31 & $12.30 \%$ \\
\hline Total & 33 & $34.74 \%$ & 39 & $24.84 \%$ & 72 & $28.57 \%$ \\
\hline \multicolumn{7}{|l|}{ University D: } \\
\hline Female & 20 & $21.05 \%$ & 20 & $12.74 \%$ & 40 & $15.87 \%$ \\
\hline Male & 4 & $4.21 \%$ & 17 & $10.83 \%$ & 21 & $8.33 \%$ \\
\hline Total & 24 & $25.26 \%$ & 37 & $23.57 \%$ & 61 & $24.21 \%$ \\
\hline \multicolumn{7}{|l|}{ Grand Total: } \\
\hline Female & 68 & $71.58 \%$ & 90 & $57.32 \%$ & 158 & $62.70 \%$ \\
\hline Male & 27 & $28.42 \%$ & 67 & $42.68 \%$ & 94 & $37.30 \%$ \\
\hline Total & 95 & $100.00 \%$ & 157 & $100.00 \%$ & 252 & $100.00 \%$ \\
\hline
\end{tabular}

\section{ANALYSIS OF SURVEY RESULTS}

\section{Impact Of Introductory AIS Course - First Partition}

To determine the influence of the introductory AIS course on students based on having either a positive or non-positive attitude towards computers before the semester (R1), mean subscale scores are first calculated at both beginning and end of semester for each group. Then, for each group by university and in total, $\mathrm{t}$-tests are performed to determine whether significant changes occur ${ }^{3}$. Table 5 summarizes the results of these tests for the data in Table 3 (first partition).

No significant change in attitudes on any subscale either in total or by university is noted amongst students that have positive attitudes at the beginning of semester. However, a significant positive change is noted for the nonpositive attitude group with respect to reduced Computer Anxiety and increased Computer Confidence. Computer Liking scores almost marginally improve ( $p$-value of 0.1081). Although only students at University A (all three subscales) and University D (Computer Anxiety) report a significant improvement for students with some degree of a non-positive attitude, all but one subscale score by university (Computer Confidence at University B) improves over the semester. 
Table 5 - Beginning Versus End of Semester Subscale Means by University and Grand Total Using Score Partition of 30

\begin{tabular}{|c|c|c|c|c|c|c|}
\hline Subscale $^{1}$ & $\begin{array}{c}\text { Mean for } \\
\text { Beginning of } \\
\text { Semester } \\
\text { Overall }<=\mathbf{3 0} \\
\end{array}$ & $\begin{array}{c}\text { Mean for } \\
\text { End of } \\
\text { Semester } \\
\text { Overall }<=\mathbf{3 0} \\
\end{array}$ & p-value ${ }^{2}$ & $\begin{array}{c}\text { Mean for } \\
\text { Beginning of } \\
\text { Semester } \\
\text { Overall }>\mathbf{3 0} \\
\end{array}$ & $\begin{array}{c}\text { Mean for } \\
\text { End of } \\
\text { Semester } \\
\text { Overall }>\mathbf{3 0} \\
\end{array}$ & p-value ${ }^{2}$ \\
\hline \multicolumn{7}{|l|}{ University A: } \\
\hline Computer Anxiety & 37.091 & 40.500 & 0.0780 & 43.793 & 44.948 & 0.1897 \\
\hline Computer Confidence & 35.091 & 38.333 & 0.0604 & 42.328 & 43.155 & 0.3499 \\
\hline Computer Liking & 26.909 & 30.750 & 0.0981 & 39.897 & 40.034 & 0.8967 \\
\hline \multicolumn{7}{|l|}{ University B: } \\
\hline Computer Anxiety & 34.286 & 37.800 & 0.3344 & 45.714 & 45.881 & 0.8621 \\
\hline Computer Confidence & 34.000 & 32.400 & 0.5540 & 43.929 & 44.476 & 0.5847 \\
\hline Computer Liking & 27.286 & 27.600 & 0.9009 & 43.119 & 41.762 & 0.2338 \\
\hline \multicolumn{7}{|l|}{ University C: } \\
\hline Computer Anxiety & 34.850 & 37.000 & 0.1887 & 44.135 & 44.885 & 0.4083 \\
\hline Computer Confidence & 32.368 & 34.350 & 0.1439 & 42.212 & 42.462 & 0.7706 \\
\hline Computer Liking & 26.750 & 27.400 & 0.5805 & 39.096 & 37.519 & 0.1235 \\
\hline \multicolumn{7}{|l|}{ University D: } \\
\hline Computer Anxiety & 29.833 & 36.250 & 0.0273 & 44.354 & 44.479 & 0.8980 \\
\hline Computer Confidence & 32.455 & 35.333 & 0.1038 & 42.583 & 42.438 & 0.8858 \\
\hline Computer Liking & 29.000 & 31.417 & 0.3117 & 40.458 & 39.583 & 0.4793 \\
\hline \multicolumn{7}{|l|}{ Grand Total: } \\
\hline Computer Anxiety & 34.060 & 37.755 & 0.0078 & 44.420 & 45.015 & 0.2604 \\
\hline Computer Confidence & 33.250 & 35.367 & 0.0288 & 42.810 & 42.965 & 0.8247 \\
\hline Computer Liking & 27.400 & 29.225 & 0.1081 & 40.500 & 39.635 & 0.1381 \\
\hline
\end{tabular}

${ }^{1}$ Each subscale contains ten questions on a five-point Likert Scale

${ }^{2}$ Bolded results are significant $\leq 0.10$

Besides these statistical comparisons, a number of other observations from Table 5 should be noted. Note that at each university and in total, students who have some degree of a non-positive attitude towards computers have scores consistently lower on all three subscales than those students with positive attitudes, both at beginning and end of semester. Also, regardless of university or in total, the Computer Liking score is the one that has the most influence on whether a student is classified as either having a non-positive or positive attitude towards computers. Further note that the mean Computer Liking score by university and in total is always the lowest of the three subscale scores, regardless of group. It is also noteworthy that the Computer Liking score is the one that changed the least over the semester.

One further observation from Table 5 bears discussion. Although attitudes for students with some degree of a non-positive attitude improve over the semester, a significant difference in attitudes is still apparent at the end of semester between them and students identified as having positive attitudes at the beginning of the semester.

\section{Impact Of Introductory AIS Course - Second Partition}

Test procedures for R1 are repeated for a score cutoff of 35, with results in Table 6 consistent with those observed in Table 5. Attitudes of students identified as having some degree of a non-positive attitude towards computers at the beginning of the semester significantly improved along the Computer Anxiety and Computer Confidence subscales. Similarly, students at University A and D show a significant improvement along one or more scales, and improvements occur in all categories except Computer Confidence at University B. 
Table 6 - Beginning Versus End of Semester Subscale Means by University and Grand Total Using Score Partition of 35

\begin{tabular}{|c|c|c|c|c|c|c|}
\hline Subscale $^{1}$ & $\begin{array}{c}\text { Mean for } \\
\text { Beginning of } \\
\text { Semester } \\
\text { Overall }<=35\end{array}$ & $\begin{array}{c}\text { Mean for } \\
\text { End of } \\
\text { Semester } \\
\text { Overall }<=35\end{array}$ & $p$-value ${ }^{2}$ & $\begin{array}{c}\text { Mean for } \\
\text { Beginning of } \\
\text { Semester } \\
\text { Overall }>35\end{array}$ & $\begin{array}{c}\text { Mean for } \\
\text { End of } \\
\text { Semester } \\
\text { Overall }>35 \\
\end{array}$ & $p$-value ${ }^{2}$ \\
\hline \multicolumn{7}{|l|}{ University A: } \\
\hline Computer Anxiety & 38.040 & 40.731 & 0.0304 & 45.386 & 42.227 & 0.3114 \\
\hline Computer Confidence & 36.040 & 38.923 & 0.0056 & 44.091 & 44.341 & 0.7779 \\
\hline Computer Liking & 30.960 & 32.962 & 0.1930 & 41.727 & 41.682 & 0.9664 \\
\hline \multicolumn{7}{|l|}{ University B: } \\
\hline Computer Anxiety & 36.917 & 38.900 & 0.4440 & 46.405 & 46.676 & 0.7566 \\
\hline Computer Confidence & 36.500 & 35.400 & 0.6275 & 45.081 & 44.676 & 0.6803 \\
\hline Computer Liking & 30.500 & 31.200 & 0.7542 & 44.216 & 42.703 & 0.1587 \\
\hline \multicolumn{7}{|l|}{ University C: } \\
\hline Computer Anxiety & 36.667 & 38.788 & 0.1077 & 45.692 & 46.000 & 0.7239 \\
\hline Computer Confidence & 34.625 & 36.303 & 0.1467 & 43.641 & 43.513 & 0.8862 \\
\hline Computer Liking & 29.455 & 29.697 & 0.8292 & 40.923 & 38.949 & 0.0713 \\
\hline \multicolumn{7}{|l|}{ University D: } \\
\hline Computer Anxiety & 34.348 & 38.522 & 0.0356 & 45.865 & 45.514 & 0.7261 \\
\hline Computer Confidence & 35.318 & 37.087 & 0.1984 & 43.892 & 43.459 & 0.6931 \\
\hline Computer Liking & 31.348 & 32.435 & 0.4834 & 42.405 & 41.378 & 0.4021 \\
\hline \multicolumn{7}{|l|}{ Grand Total: } \\
\hline Computer Anxiety & 36.495 & 39.283 & 0.0042 & 45.815 & 46.108 & 0.5469 \\
\hline Computer Confidence & 35.429 & 37.141 & 0.0198 & 44.166 & 44.006 & 0.7087 \\
\hline Computer Liking & 30.462 & 31.467 & 0.3125 & 42.274 & 41.720 & 0.0636 \\
\hline
\end{tabular}

${ }^{1}$ Each subscale contains ten questions on a five-point Likert Scale

${ }^{2}$ Bolded results are significant $\leq 0.10$

For students with positive attitudes before the semester, one difference is noted between Tables 5 and 6 . The partition of 35 results in a significant decrease in Computer Liking, both in total and at University C. While not statistically significant, decreases are also noted at the other universities. Note that this decrease occurs for the one subscale that, like in Table 5, is always the lowest mean score by university and total, regardless of group. Also consistent with Table 5, significant differences are still apparent at the end of the semester along all three subscales between the two partitioned groups, regardless of university or in total.

\section{Differences In Impact By Gender - Both Partitions}

$\mathrm{R} 2$ asks whether there is a difference in attitude changes by partitioned group, based on gender. We answer this question by first calculating the mean scores of each subscale at both beginning and end of semester by gender for each group. We then perform t-tests to determine whether the amount of change in attitude differed by gender within each group. Table 7 summarizes the results of these tests with the cutoff point of 30 , while Table 8 summarizes the results with the cutoff point of 35. No significant differences are noted in either table, therefore indicating no difference in the influence of the introductory AIS course on the attitudes of students whether having positive or nonpositive attitudes, based on gender. 
Table 7 - Difference in Change Over Semester by Gender Using Score Partition of 30

\begin{tabular}{|c|c|c|c|c|c|}
\hline Subscale $^{1}$ & $\begin{array}{c}\text { Mean for } \\
\text { Beginning of } \\
\text { Semester } \\
\text { Overall }<=30 \\
\text { Female } \\
\end{array}$ & $\begin{array}{c}\text { Mean for } \\
\text { End of } \\
\text { Semester } \\
\text { Overall }<=30 \\
\text { Female } \\
\end{array}$ & $\begin{array}{c}\text { Mean for } \\
\text { Beginning of } \\
\text { Semester } \\
\text { Overall }<=30 \\
\text { Male } \\
\end{array}$ & $\begin{array}{c}\text { Mean for } \\
\text { End of } \\
\text { Semester } \\
\text { Overall }<=30 \\
\text { Male } \\
\end{array}$ & $\begin{array}{c}\text { p-value } \\
\text { for Difference } \\
\text { in Change } \\
\text { Over Semester } \\
\text { by Gender } \\
\end{array}$ \\
\hline Computer Anxiety & 34.200 & 38.200 & 33.733 & 36.643 & 0.6688 \\
\hline Computer Confidence & 33.176 & 35.257 & 33.429 & 35.643 & 0.9451 \\
\hline \multirow[t]{2}{*}{ Computer Liking } & 27.514 & 28.643 & 27.133 & 29.457 & 0.8391 \\
\hline & $\begin{array}{c}\text { Mean for } \\
\text { Beginning of } \\
\text { Semester } \\
\text { Overall }>\mathbf{3 0} \\
\text { Female } \\
\end{array}$ & $\begin{array}{c}\text { Mean for } \\
\text { End of } \\
\text { Semester } \\
\text { Overall > } 30 \\
\text { Female } \\
\end{array}$ & $\begin{array}{c}\text { Mean for } \\
\text { Beginning of } \\
\text { Semester } \\
\text { Overall }>\mathbf{3 0} \\
\text { Male } \\
\end{array}$ & $\begin{array}{c}\text { Mean for } \\
\text { End of } \\
\text { Semester } \\
\text { Overall }>\mathbf{3 0} \\
\text { Male } \\
\end{array}$ & $\begin{array}{c}\text { p-value } \\
\text { for Difference } \\
\text { in Change } \\
\text { Over Semester } \\
\text { by Gender }\end{array}$ \\
\hline Computer Anxiety & 44.172 & 44.975 & 44.808 & 45.076 & 0.5740 \\
\hline Computer Confidence & 42.492 & 42.810 & 43.308 & 43.203 & 0.6599 \\
\hline Computer Liking & 40.066 & 39.174 & 41.179 & 40.342 & 0.9628 \\
\hline
\end{tabular}

${ }^{1}$ Each subscale contains ten questions on a five-point Likert Scale

${ }^{2}$ Bolded results are significant $\leq 0.10$

Table 8 - Difference in Change Over Semester by Gender Using Score Partition of 35

\begin{tabular}{|c|c|c|c|c|c|}
\hline Subscale $^{1}$ & $\begin{array}{c}\text { Mean for } \\
\text { Beginning of } \\
\text { Semester } \\
\text { Overall }<=35 \\
\text { Female }\end{array}$ & $\begin{array}{c}\text { Mean for } \\
\text { End of } \\
\text { Semester } \\
\text { Overall }<=35 \\
\text { Female }\end{array}$ & $\begin{array}{c}\text { Mean for } \\
\text { Beginning of } \\
\text { Semester } \\
\text { Overall }<=35 \\
\text { Male }\end{array}$ & $\begin{array}{c}\text { Mean for } \\
\text { End of } \\
\text { Semester } \\
\text { Overall }<=35 \\
\text { Male } \\
\end{array}$ & $\begin{array}{c}\text { p-value } \\
\text { for Difference } \\
\text { in Change } \\
\text { Over Semester } \\
\text { by Gender }\end{array}$ \\
\hline Computer Anxiety & 36.687 & 39.657 & 36.000 & 38.280 & 0.7035 \\
\hline Computer Confidence & 35.470 & 37.149 & 35.320 & 37.120 & 0.9352 \\
\hline \multirow[t]{2}{*}{ Computer Liking } & 30.687 & 31.866 & 29.884 & 30.400 & 0.6920 \\
\hline & $\begin{array}{c}\text { Mean for } \\
\text { Beginning of } \\
\text { Semester } \\
\text { Overall }>35 \\
\text { Female } \\
\end{array}$ & $\begin{array}{c}\text { Mean for } \\
\text { End of } \\
\text { Semester } \\
\text { Overall > 35 } \\
\text { Female } \\
\end{array}$ & $\begin{array}{c}\text { Mean for } \\
\text { Beginning of } \\
\text { Semester } \\
\text { Overall }>35 \\
\text { Male } \\
\end{array}$ & $\begin{array}{c}\text { Mean for } \\
\text { End of } \\
\text { Semester } \\
\text { Overall }>35 \\
\text { Male } \\
\end{array}$ & $\begin{array}{c}\text { p-value } \\
\text { for Difference } \\
\text { in Change } \\
\text { Over Semester } \\
\text { by Gender } \\
\end{array}$ \\
\hline Computer Anxiety & 45.867 & 46.315 & 45.746 & 45.838 & 0.6912 \\
\hline Computer Confidence & 44.122 & 44.101 & 44.224 & 43.882 & 0.7413 \\
\hline Computer Liking & 42.167 & 40.854 & 42.418 & 41.588 & 0.6749 \\
\hline
\end{tabular}

${ }^{1}$ Each subscale contains ten questions on a five-point Likert Scale

${ }^{2}$ Bolded results are significant $\leq 0.10$

\section{Prior Computer Experience - Both Partitions}

Prior research reports a direct relationship between computer experience and attitudes. An examination of responses to survey experience questions confirms this relationship. Table 1 shows the mean responses to the beginning of the semester answer to the experience questions for students with positive and non-positive attitudes based on the respective cutoff points of 30 and 35. A t-test is performed for each question by partition to determine whether there is a difference in experience between the two groups, with two-tailed p-values also shown in Table 1.

Of the twenty-seven experience questions asked, seventeen are significantly different between the positive and non-positive attitude groups for the partition of 30 . Sixteen of these questions indicate that the positive attitude group has significantly more experience than the non-positive group. The one experience question (E8) that does not favor the students with positive attitudes is, "How often do you use the college computer labs?" The result of asking this question may actually indicate that students exhibiting some degree of a non-positive attitude have less computer experience because their use of college computer labs is likely due to them having limited access to computers at 
either home (E7) or work (E9). Computer lab usage may have a negative impact on computer attitudes because of inconveniences with time and location, discomfort with surroundings, and/or lab distractions.

Using the partition of 35 , twenty questions are significantly different between the two groups. Nineteen questions indicate that the students identified as having positive computer attitudes have more computer experience than those having some degree of a non-positive attitude. Consistent with the results of the partition at 30 , the one experience question (E8) where the non-positive attitude group reports significantly more experience is, "How often do you use the college computer labs?" Summarizing results in Table 1, prior computer experience (or lack thereof) is strongly associated with an accounting student's attitudes towards computers.

As one last comment about computer experience, although responses to a number of questions show a relationship between experience and attitudes, responses to two experience questions did not differ between groups in either partition. The number of prior computer courses, taken either before or in college (E10 and E11), does not significantly differ using either partition. This result, when considered with the result that responses for many other experience questions significantly differ, may indicate that prerequisites are not sufficient for ensuring students have equal experience with computer technology before taking an introductory AIS course. Experience appears to also be gained elsewhere, such as through work or personal initiative of learning computer technology.

\section{Students With Negative Attitudes}

As further exploratory analysis, we partition the data a third time using a cutoff score of 25 , a score that can appropriately be described as a negative attitude towards computers. Using this cutoff, 24 of the 252 students (approximately 10\%) exhibit some type of negative attitude, with 13 having a score of 25 or less for Computer Liking. Because of small sample sizes by both University and gender for students with negative attitudes, we chose not to include this data analysis with that for data partitioned at both 30 and 35 but to further emphasize the results found from using the other two partitions.

Table 9 summarizes the comparison of beginning to end of semester for the negative and non-negative partitions. Results are consistent with those using cutoffs of 30 and 35, and are even stronger support that students with poor attitudes towards computers are influenced most by the AIS course. Consistent with previous results, Computer Liking has the lowest means amongst the subscales at beginning and end of semester for both partitioned groups. Significant improvements at end of semester are noted for every subscale for students reporting a negative attitude while no significant changes are noted for students with non-negative attitudes. Although significant changes are found for all three subscales for students with negative attitudes (as opposed to only Computer Anxiety and Computer Confidence for students with non-positive attitudes), improvements in both Computer Anxiety and Computer Confidence are much greater than that for Computer Liking, a result consistent with prior results. Also consistent with previous results is that while the gap between the two partitioned groups is reduced, a substantial difference still exists after the course.

Table 9 - Beginning Versus End of Semester Subscale Means in Grand Total Using Score Partition of 25

\begin{tabular}{|c|c|c|c|c|c|c|}
\hline Subscale $^{1}$ & $\begin{array}{c}\text { Mean for } \\
\text { Beginning of } \\
\text { Semester } \\
\text { Overall }<=25\end{array}$ & $\begin{array}{c}\text { Mean for } \\
\text { End of } \\
\text { Semester } \\
\text { Overall }<=25\end{array}$ & p-value ${ }^{2}$ & $\begin{array}{c}\text { Mean for } \\
\text { Beginning of } \\
\text { Semester } \\
\text { Overall }>25\end{array}$ & $\begin{array}{c}\text { Mean for } \\
\text { End of } \\
\text { Semester } \\
\text { Overall }>25\end{array}$ & $\begin{array}{c}\text { p- } \\
\text { value }^{2}\end{array}$ \\
\hline Computer Anxiety & 30.500 & 36.773 & 0.0012 & 43.491 & 44.247 & 0.1192 \\
\hline Computer Confidence & 30.900 & 35.227 & 0.0043 & 41.842 & 42.075 & 0.6341 \\
\hline Computer Liking & 25.773 & 29.318 & 0.0669 & 38.388 & 39.048 & 0.2826 \\
\hline
\end{tabular}

'Each subscale contains ten questions on a five-point Likert Scale

${ }^{2}$ Bolded results are significant $\leq 0.10$

With respect to prior experience, results using the partition of 25 are also consistent with those discussed for partitions of 30 and 35. Mean responses to nine experience questions significantly differ between the two groups, with 
responses to eight questions (E15, E16, E18, E21, E22, E23, E24 and E32) indicating that students with non-negative attitudes have more experience before taking the AIS course. The one question that indicates students with negative attitudes having more experience is consistent with results for the other two partitions - students with negative attitudes report more experience using computer labs at school (E8). Also consistent with prior results is no significant difference in the amount of prior computer courses before or in college (E10 and E11).

\section{SUMMARY AND CONCLUSIONS}

Our study is the first to categorize students into different groups based on their attitudes towards computers before taking an introductory AIS course and look at the impact of the course on their attitudes. We survey students about their computer experience and attitudes before taking an introductory AIS course, and then again at the end of semester for their attitudes. We partition the data multiple ways for studying how the course influences certain categories of students based on their beginning of the semester attitudes. Results indicate that the course can help improve the attitudes that some accounting students have towards technology.

Results indicate that a substantial number of accounting students surveyed $(20-40 \%$, depending on the partition) have some degree of a non-positive attitude towards computers before taking the introductory AIS course. Results also indicate that these students are the ones whose computer attitudes are most influenced by the course, with the influence a positive one on two of three attitude dimensions measured. A partition identifying students with negative attitudes shows improvement on all three dimensions. While these are promising results, attitudes along one dimension (Computer Liking) are consistently the least positive, with ratings on this subscale typically causing a student to be classified as having some degree of a non-positive (negative) attitude. Computer liking actually declined for students identified in one partition as having positive attitudes before the semester. Such results give credence to concerns expressed by AIS educators that students may be apprehensive towards and uneasy with course material. Also tempering our findings is the substantial gap that still exists at the end of the semester between students in each of the three partitions. This implies that a single AIS course may reduce a computer attitude gap between students but not totally close it.

Our results do not note any differences in how the introductory AIS course influenced computer attitudes, based on gender. While much research has reported differences by gender for people, in general, our study provides more evidence confirming results from the few prior accounting studies that no computer attitudinal difference exists between male and female accounting students. A final result of our study shows that prior computer experience appears to help explain a student's classification as having either positive or non-positive (non-negative or negative) attitudes towards computers. Students reporting positive (non-negative) computer attitudes resoundingly reported more computer experience than those who reported non-positive (negative) attitudes. This experience appears to be gained outside of computer courses taken before or in college.

AIS and accounting educators should find our results useful and informative. AIS educators should be cognizant that their courses can change certain attitudes of many students. They should also be cognizant that some attitudes (such as computer liking) are not as strong as other attitudes and may not be influenced by AIS courses. They should also be aware that positive attitudes may decline after taking AIS courses. AIS educators should consider all the implications that their courses may have on students, and integrate technology when possible and carefully. We do not suggest that technology be implemented for the sake of improving attitudes, but suggest that technology be leveraged to its fullest to improve the attitudes of students towards the greatest amount of AIS course material to be learned.

Accounting educators can also use our results for determining the adequacy of prerequisites and considering implementing technology in other accounting courses. With some student attitudes improving with experience, computer-based assignments using Excel, Access, XML, XBRL and/or an ERP package, for example, in such courses as financial accounting, cost accounting, tax, auditing, etc. may help improve some attitudes towards course subject matter had technology not been leveraged. Accounting departments may consider our results and determine whether some of their students have more computer experience (and therefore more positive computer attitudes) than other students, and how this gap can be reduced. Accounting departments may want to survey students to gain perspective 
on any attitude differences that may exist and to what extent. Our results should be useful when discussing such initiatives as increasing the number of required technology courses, or implementing a mandatory laptop program.

The profession demands that those entering the profession have strong computer skills, and prior research shows how computer attitudes are directly related to both work performance and satisfaction. Accounting educators are therefore being called upon to increase their coverage of technology in their curriculums to meet the needs of the profession (Albrecht and Sack, 2000). Our study provides evidence that computer exposure can improve computer attitudes, which in turn, should improve attitudes towards related subject matter being taught, thereby helping prepare students for productive and satisfying careers.

Our study has certain limitations. While students in each course at each university were taught a number of similar concepts, differences in curriculums, instructors, and course content may have impacted results. Also, surveys are self-reported perceptions and may not reflect actual levels of experience and/or relative attitudes. Further, only responses from those present when the survey was administered are included in our study. Despite these limitations, consistent results across the four universities indicate strong external validity of our study.

\section{SUGGESTIONS FOR FUTURE RESEARCH}

Further studies are needed for determining the influence of computer technology on accounting students. Studies can focus on the relationship between aptitude, such as GPA or actual performance in AIS courses, and computer attitudes. Many universities have implemented on-line courses, as well as courses that may meet but where many aspects (tests, quizzes, assignments, homework) are done electronically. Studies can measure the influence such courses have on attitudes and performance. Other studies can focus on why accounting students have less favorable attitudes along the dimension of liking computers. Identifying why can help accounting and AIS educators devise methods for improving attitudes, thereby increasing a student's ability to have a successful and satisfying career. These and other studies can provide meaningful insights that can help positively shape both accounting and AIS education and the accounting profession.

The authors thank David C. Hayes, Paul D. Hutchison, Jeffrey W. Strawser, and Ronald M. Young for their assistance. The authors also thank anonymous reviewers and participants at the 2005 AIS Educator Conference for helpful suggestions for improving this study.

\section{ENDNOTES}

${ }^{1}$ A total of 93 surveys from either beginning or end of semester are not used because they could not be matched from beginning to end of semester. Of the 93, 63 are from the beginning of semester. A total of 41 students from the four universities withdrew from the course. Incomplete data does not allow us to match these students with surveys. Discussed in later sections of this study, we use two cutoffs to partition data between students with positive versus non-positive attitudes - scores of 30 and 35 . Of the 63 students, 10 had scores that would classify them as nonpositive at a cutoff of 30, with 8 having a score of 30 or less for Computer Liking. Similarly, 21 students had scores that would classify them as non-positive at a cutoff of 35, with 18 having a score of 35 or less for Computer Liking. The 63 surveys have mean scores of 42.48 for Computer Anxiety, 41.13 for Computer Confidence, and 37.41 for Computer Liking. These scores are higher than those partitioned as non-positive at respective cutoffs of 30 and 35 (see Tables 5 and 6). While the data for beginning of semester unmatched surveys is consistent with certain aspects of the data used in our study (aspects discussed in later sections), the means do not indicate less positive attitudes. Less positive scores from these surveys might be expected for a number of these students, specifically those who may have withdrawn because of an inability to grasp course material. We draw no formal conclusion, however, because some of the students could have withdrawn for some other reason, as well as the lack of measuring attitudes at the time of withdrawal. 
${ }^{2}$ Loyd and Gressard (1984) report Alpha reliability coefficients of $.86, .91, .91$ and .95 for each subscale and in total, respectively. As a validated survey instrument, the CAS has been widely used in a variety of studies that measure computer attitudes. Although not specific to AIS course content, AIS courses include a wide breadth in coverage of computers and IT for learning AIS concepts. This can be seen in our study where students, depending on the university, were exposed to spreadsheets, databases, and/or ERP software while taking the introductory AIS course. We therefore believe a validated survey instrument that measures attitudes towards a wide-range of computer technology is reasonable and appropriate to use.

${ }^{3}$ Possible differences amongst students due to university, instructor, course content, nature of computing experience, etc., may exist. Only one university had multiple instructors (University C), and both instructors used the same course materials. A number of potential differences are controlled for by analyzing results by university.

\section{REFERENCES}

1. $\quad$ Albrecht, W.S. and R.J. Sack, Accounting Education: Charting the Course Through a Perilous Future, Vol. 16, American Accounting Association, Sarasota, FL, USA, 2000.

2. American Institute of Certified Public Accountants (AICPA), http://www.cpaexam.org/download/CSOs\%20for\%20revised\%20CPA\%20Exam.pdf, 2005.

3. Bain, C. E., A. I. Blankley, and L. M. Smith, An Examination of Topical Coverage for the First Accounting Information Systems Course, Journal of Information Systems, Vol. 16, No. 2, pp. 143-164, 2002.

4. Basile, A. and J.M. D'Aquila, An Experimental Analysis of Computer-Mediated Instruction and Student Attitudes in a Principles of Financial Accounting Course, Journal of Education for Business, Vol. 3, No. 1, pp. 137-143, 2002.

5. $\quad$ Briscoe, N.R., G.W. Glezen, and W.C. Letzkus, The Association of Accounting Course Content Groupings and Student Evaluations, Accounting Educators' Journal, Vol. 8, No. 2, pp. 14-26, 1996.

6. Daigle, R. J. and P. W. Morris, Gender Differences in Accounting Student Attitudes and Experience Towards Computers, Review of Accounting Information Systems, Vol. 3, No. 4, pp. 75-84, 1999.

7. Dunn, C. and S. Grabski, The Effect of Field Dependence on Conceptual Modeling Performance, Advances in Accounting Information Systems, Vol. 6, pp. 65-77, 1998.

8. Ferguson, C., The Effects of Microcomputers on the Work of Professional Accountants, Accounting and Finance, Vol. 37, No. 1, pp. 41-67, 1997.

9. Harris, A. L., The Impact of the Introductory MIS Course on Students' Attitudes and Perceptions Towards Computers, The Journal of Computer Information Systems, Vol. 33, pp. 33-41, 1992.

10. Institute of Internal Auditors (IIA), http://www.theiia.org/index.cfm?doc id=22, 2005.

11. Institute of Management Accountants (IMA), http://www.imanet.org/ima/docs/600/564.pdf, 2005.

12. Jones, R.A., University Student's Perceptions of Computer Instruction Within the College of Business, Proceedings of the American Accounting Association Western Regional Meeting, 2001.

13. Lowe, G. S. and H. Krahn, Computer Skills and Use Among High School and University Graduates, Canadian Public Policy, Vol. 15, pp. 175-188, June 1989.

14. Loyd, B. H. and C. P. Gressard, Reliability and Factorial Validity of Computer Attitude Scales, Educational and Psychological Measurement, Vol. 44, pp. 501-505, 1984.

15. Mills, T. A., An Examination of the Relationship Between Accountants' Scores on Field Independence and Use of and Attitude Toward Computers, Perceptual and Motor Skills, Vol. 81, pp. 715-720, 1997.

16. Morris, P.W. and R.J. Daigle, Student Attitudes Towards Computers Before and After Taking An Introductory AIS Course, Journal of Business and Economic Research, Vol. 2, No. 7, 2004.

17. Omar, M. H., Impact of the MIS Course on Business Student Attitudes to Computers and on Their Understanding of Information Systems Concepts, The Journal of Computer Information Systems, Vol. 32, No. 1, pp. 36-39, 1991.

18. Orr, C., D. Allen, and S. Poindexter, The Effect of Individual Differences on Computer Attitudes: An Empirical Study, Journal of End User Computing, Vol. 13, No. 2, pp. 26-39, 2001.

19. Orpen, C. and C. Ferguson, The Attitudes of Accounting Students to Working with Computers: A Preliminary Study, Accounting and Finance, Vol. 31, No. 2, pp. 113-119, 1991. 
20. Quereshi, S. and C. Hoppel, Profiling Computer Predispositions, Journal of Professional Services Marketing, Vol. 12, pp. 73-83, 1995.

21. Ravel, V., Perspectives on Students' Teaching Evaluations of AIS Courses, The Journal of Information Systems, Vol. 5, No. 2, pp. 62-72, 1991.

22. Sax, L. J., A. W. Astin, W. S. Korn, and K. M. Mahoney, The American Freshman: National Norms for Fall 2000, Higher Education Research Institute, UCLA Graduate School of Education \& Information Studies, 2000.

23. Seyal, A. H., M. M. Rahim, and M. N. A. Rahman, A Study of Computer Attitudes of Non-Computing Students of Technical Colleges in Brunei Darussalam, Journal of End User Computing, Vol. 14, No. 2, pp. 40-47, 2002.

24. Torkzaheh, G. and X. Koufteros, Computer User Training and Attitudes: A Study of Business Undergraduates, Behaviour \& Information Technology, Vol. 12, No. 5, pp. 284-292, 1993.

25. Young, B. J., Gender Differences in Student Attitudes Toward Computers, Journal of Research on Computing in Education, Vol. 33, No. 2, pp. 204-216, 2000.

\section{NOTES}




\section{NOTES}

